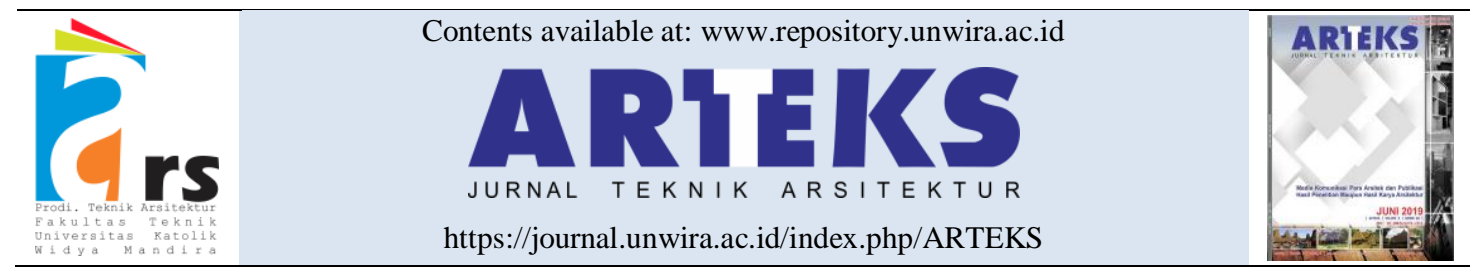

Research paper

doi: 10.30822/arteks.v5i2.366

\title{
Kajian penerapan arsitektur organik pada kawasan agrowisata
}

\author{
Gina Liana Wati, Anisa*(C)
}

Program Studi Magister Arsitektur, Fakultas Teknik, Universitas Muhammadiyah Jakarta Jl. Cempaka Putih Tengah no. 27, Jakarta Pusat 10510, Indonesia



\begin{tabular}{l}
\hline ARTICLE INFO \\
\hline Article history: \\
Received January 11, 2020 \\
Received in revised form January 20, \\
2020 \\
Accepted March 11, 2020 \\
Available online August 01, 2020
\end{tabular}

Keywords:
Agro-tourism area
Modern tourism
Organic architecture

"Corresponding author: Anisa Program Studi Arsitektur, Fakultas Teknik, Universitas Muhammadiyah Jakarta, Indonesia Email: anisa@ftumj.ac.id ORCID: https://orcid.org/0000-0002-6295$426 \mathrm{X}$

ABSTRACT
Organic architectural study on agro-tourism areas

Organic architecture is a concept in architecture that is in harmony with nature and integrated with the site through visualization. There are eight basic concepts that can be used as a reference in designing organic architectural building concepts, namely, building as nature, continuous present, form follows flow, of the people, of the hill, of the material, youthful and unexpected, Living music. modern agrotourism areas can liven up the atmosphere of modern agro-tourism areas, so as to increase the attractiveness of these modern agrotourism areas. This study used a deductive method to find out more about the application of organic architecture in the Farm Kuntum region. The analysis was conducted descriptively qualitatively using the theory of eight organic architectural concepts. The conclusion obtained is that the concept of organic architecture can be applied to modern agro-tourism areas, including applying open mass compositions and resembling organisms, presenting natural elements, and making nature part of the design an application of the building is nature concept. The form follows flow is applied to modern agro-tourism areas by designing the longest side of the building to the north and south, designing the building with openings, and designing an open area leading to a beautiful natural environment. Of the people is applied to modern agro-tourism areas by providing sufficient space for visitors to interact with animals and design buildings with open spaces that can accommodate large crowds.

\section{Pendahuluan}

Arsitektur organik merupakan konsep arsitektur yang diperkenalkan oleh Frank Lloyd Wright melalui karyanya yaitu House of Falling Water (Rasikha 2009). Menurutnya arsitektur organik mengutamakan pada keselarasan arsitektur, manusia, dan lingkungan alam sekitar (Setyoningrum and Anisa 2019). Selain itu, menurut Frank Lloyd Wright dalam kajian Sujanra, Mustaqimmah dan Wahyuwibowo (2017) mengatakan bahwa arsitektur organik harus memiliki keselarasan dengan alam dan terintegeritas dengan tapak melalui visualisasinya
(Muzha 2013). Menurut Widati (2015), karyakarya Frank selalu berakar pada tempat dimana arsitektur itu berada karena selalu terinspirasi dan menyatu dengan alamnya (Widati 2015). Meskipun demikian, arsitektur organik bukan merupakan sebuah bentuk yang imitasi atau tiruan terhadap alam sekitar (Rukayah 2003). Selain Wright, ada banyak arsitek terkenal di dunia yang menerapkan arsitektur organik pada bangunannya. Setiap arsitek memiliki definisi masing-masing mengenai arsitektur organik yang tercermin dari karyanya. Beberapa arsitek yang menerapkan konsep arsitektur organik pada 
bangunannya antara lain Alvar Aalto, Louis Henry Sullivan dan Hugo Haring (Rasikha 2009).

Menurut Frank Lloyd Wright, arsitektur organik memiliki delapan konsep dasar yang dijadikan sebagai acuan dalam mendesain sebuah bangunan (Nagoy and Sela 2016). Konsep dasar tersebut yaitu, building as nature, continous present, form follows flow, of the people, of the hill, of the material, youthful and unexpected, living music. Dengan menerapkan delapan konsep dasar tersebut pada arsitektur maka kesan arsitektur yang menyatu dengan alam dapat tercipta (Widodo 2019; Subroto 2019). Salah satu penelitian yang pernah dilakukan pada kawasan taman, mengkaitkan antara salah satu prinsip arsitektur organik dengan aksesibilitas difabel, didapatkan kesimpulan salah satunya bahwa beberapa elemen di taman seperti memanfaatkan kontur dan pengaturan vegetasi merupakan aplikasi dari arsitektur organik pada taman (Masruroh, Mauliani, and Anisa 2015).

Indonesia memiliki potensi yang besar untuk mengembangkan industri pariwisata (Rahma and Handayani 2013). Pernyataan tersebut juga didukung dengan data World Tourism Organization dalam kajian Basiya dan Rozak tahun 2012, menyatakan bahwa kunjungan wisatawan di Indonesia meningkat sebesar 7,6\% setiap tahunnya (Basiya and Rozak 2012; Pudianti and Vitasurya 2019; Koy and Rodrigues 2019; Bawole 2020). Agrowisata merupaan salah satu jenis wisata pertanian yang kini mulai diminati (Pamulardi 2006). Kawasan agrowisata modern merupakan kegiatan pariwisata yang memanfaatkan potensi alam, pertanian (agro), budaya, dan aktivitas masyarakat pedesaan sebagai daya tarik (Gunawan 2016). Kegiatan Agro merupakan usaha pertanian yang dapat diklasifikasi menajdi empat kelompok, yaitu tanaman pangan, hortikultura, perkebunan, kehutanan, peternakan dan perikanan (Suhato 2016). Agrowisata juga diharapkan dapat menambah penghasilan para petani, meningkatkan kelestarian alam, budaya dan teknologi lokal dalam mengolah pertanian yang sudah digunakan secara turun-temurun (Muzha 2013).

Dalam pengembangannya, agrowisata didukung oleh kondisi alam yang sejuk dan memungkinkan untuk kegiatan wisata alam (Susetyaningsih 2013). Wisata alam memiliki daya tarik yang meliputi pemandangan alam daratan, larutan, pantai, iklim dan ciri khas kondisi geografis lainnya (Basiya and Rozak
2012). Pernyataan tersebut dapat didukung dengan pernyataan Sujanra, Mustaqimmah, dan Wahyuwibowo (2017) yang menyatakan bahwa arsitektur organik dapat menciptakan keselarasan secara visual antara tapak dan lingkungan alam sekitar (Sujanra, Mustaqimmah, and Wahyuwibowo 2017). Selain itu juga, menurut Dalawir, Tilaar dan Poli (2015) dalam penelitiannya menyataan bahwa arsitektur organik pada kawasan industri berbasis wisata dapat memberikan kesan yang menyatu dengan alam tanpa merusak lingkungan alam sekitar (Dalawir, Tilaar, and Poli 2015). Sehingga dengan adanya pernyataan yang saling mendukung tersebut, penuls menyimpulkan bahwa penerapan arsitektur organik pada kawasan agrowisata dapat menciptakan kesan yang lebih menyatu dengan alam.

Beberapa permasalahan yang muncul menyangkut penerapan arsitektur organik pada kawasan agrowisata modern antara lain, bagaimana penerapan arsitektur organik pada kawasan agrowisata modern dan elemen-elemen apa saja yang menunjukkan bahwa kawasan agrowisata telah menerapkan arsitektur organik. Berdasarkan permasalahan tersebut, dilakukanlah penelitian ini yang bertujuan untuk mengetahui penerapan arsitektur organik dan elemen-elemen apa saja yang menandakan arsitektur organik pada kawasan agrowisata.

\section{Metode penelitian}

Penelitian ini menggunakan pendekatan rasionalistik deduktif, dengan metode deskriptif kualitatif. Pendekatan deduktif dipilih karena penelitian ini berangkat dari pengetahuan penulis mengenai teori arsitektur organik dan agrowisata, kemudian penulis melakukan observasi dan menyesuaikan fakta-fakta lapangan dengan teori tersebut. Data dalam penelitian ini didapatkan dari proses observasi lapangan yang kemudian diolah menggunakan software Autocad 2012. Hasil dari obesrvasi tersebut berupa data site plan, blok plan, dan tampak kawasan.

Analisis dilakukan secara singkat dengan mengidentifikasi delapan konsep dasar arsitektur organik pada kawasan agrowisata yang dicetuskan oleh Frank Llyod Wright, yaitu building as nature, continous present, form follows flow, of the people, of the hill, of the material, youthful and unexpected, living music 
(Nagoy and Sela 2016). Setelah dilakukan tahap tersebut, maka dapat ditarik kesimpulan berupa konsep dan elemen-elemen yang dapat menunjukan penerapan aristektur organik pada kawasana agrowisata.

Studi kasus yang dipilih adalah Kuntum Farmfield dengan beberapa alasan, yaitu kawasan agrowisata yang diminati banyak pengunjung karena selalu ramai dan memiliki visusalisai yang selaras dengan lingkungan alam sekitar. Berdasarkan data yang didapatkan melalui google maps, Kuntum Farmfield berlokasi di Jalan Raya Tajur No. 291, Sindangrasa, Kec. Cisarua, Bogor, Jawa Barat, dengan luas 6,16 hektare (Lihat gambar 1).

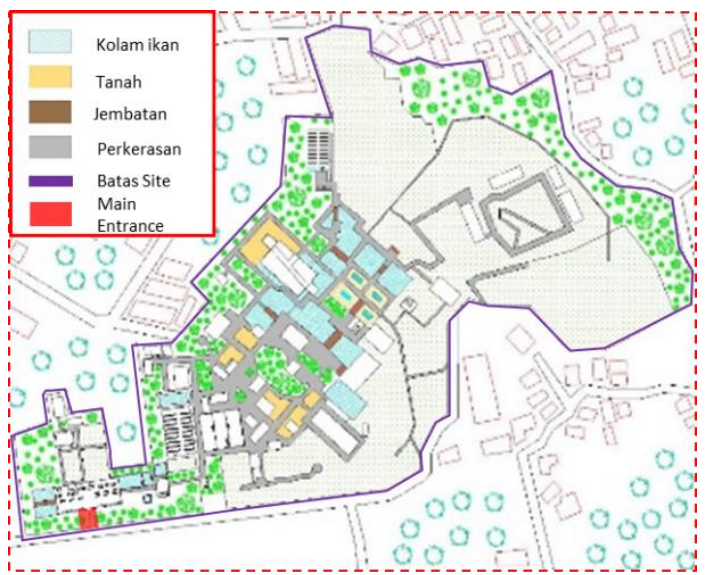

Gambar 1. Kuntuk Farmfield

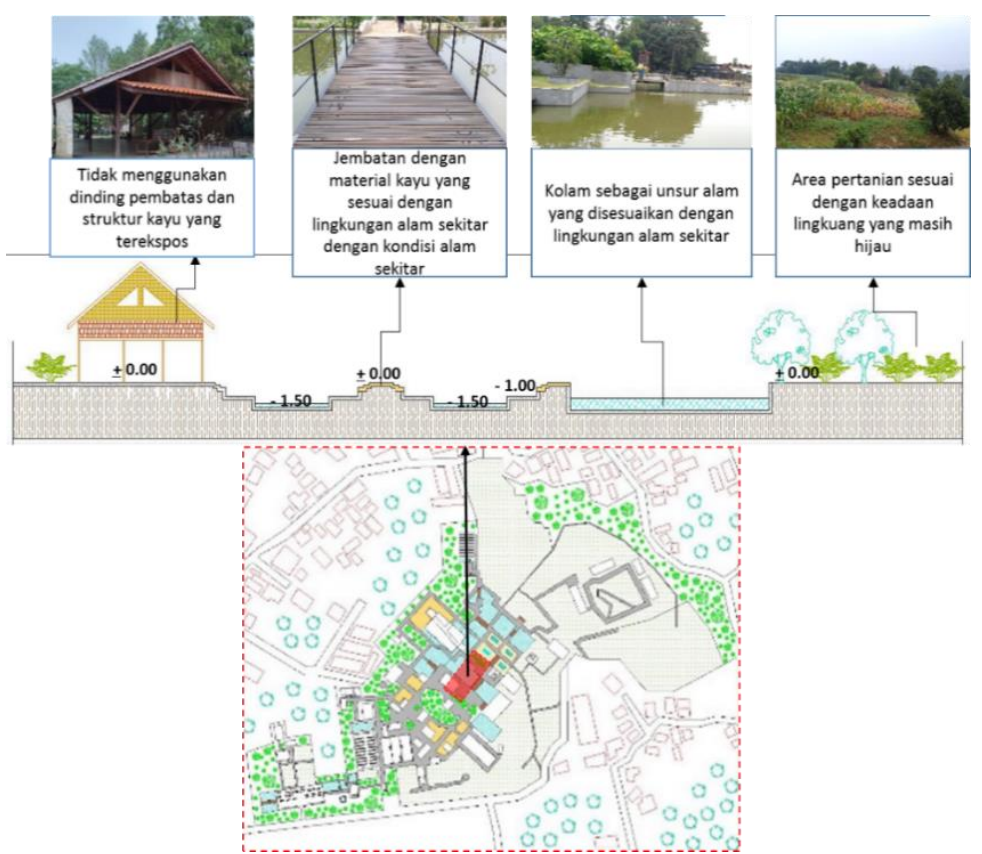

\section{Temuan dan pembahasan}

\section{Building is nature}

Konsep building is nature yaitu konsep pada arsitektur yang diterapkan sehingga dapat menimbulkan kesan menyatu dengan alam (Nagoy and Sela 2016). Building is nature diterapkan pada Kuntum Farmfield dengan mengaplikasikan desain bangunan yang menggunakan struktur kayu dan meminimalisir dinding pembatas. Struktur kayu pada bangunan yang terekspos memberikan keselarasan dengan lingkungan alam sekitar yang merupakan pegunungan dengan pepohonan hijau. Sedangkan desain bangunan dengan minimnya dinding pembatas memungkinkan masuknya view alam sekitar yang masih asri, sehingga memberikan kesan menyatu dengan alam sekitar. Selain itu desain tapak yang banyak mengandung unsur alam seperti, jembatan dan kolam yang menambah kesan selaras dan menyatu dengan alam sekitar yang merupakan pepohonan dan pegunungan hijau (Lihat gambar 2).

Gambar 2. Konsep building is nature 


\section{Continous present}

Konsep continous present merupakan konsep yang diterapkan pada arsitektur sehingga sebuah desain dapat terus berlanjut dan berkembang mengikuti perkembangan zaman (Nagoy and Sela 2016). Continous present diterapkan pada Kuntum Farmfield dengan menerapkan sistem multi massa pada tapak kawasan yang luas. Letak massa bangunan yang berjauhan satu sama lain pada lahan yang luas memungkinkan kawasan untuk dapat terus berembang dalam desainnya

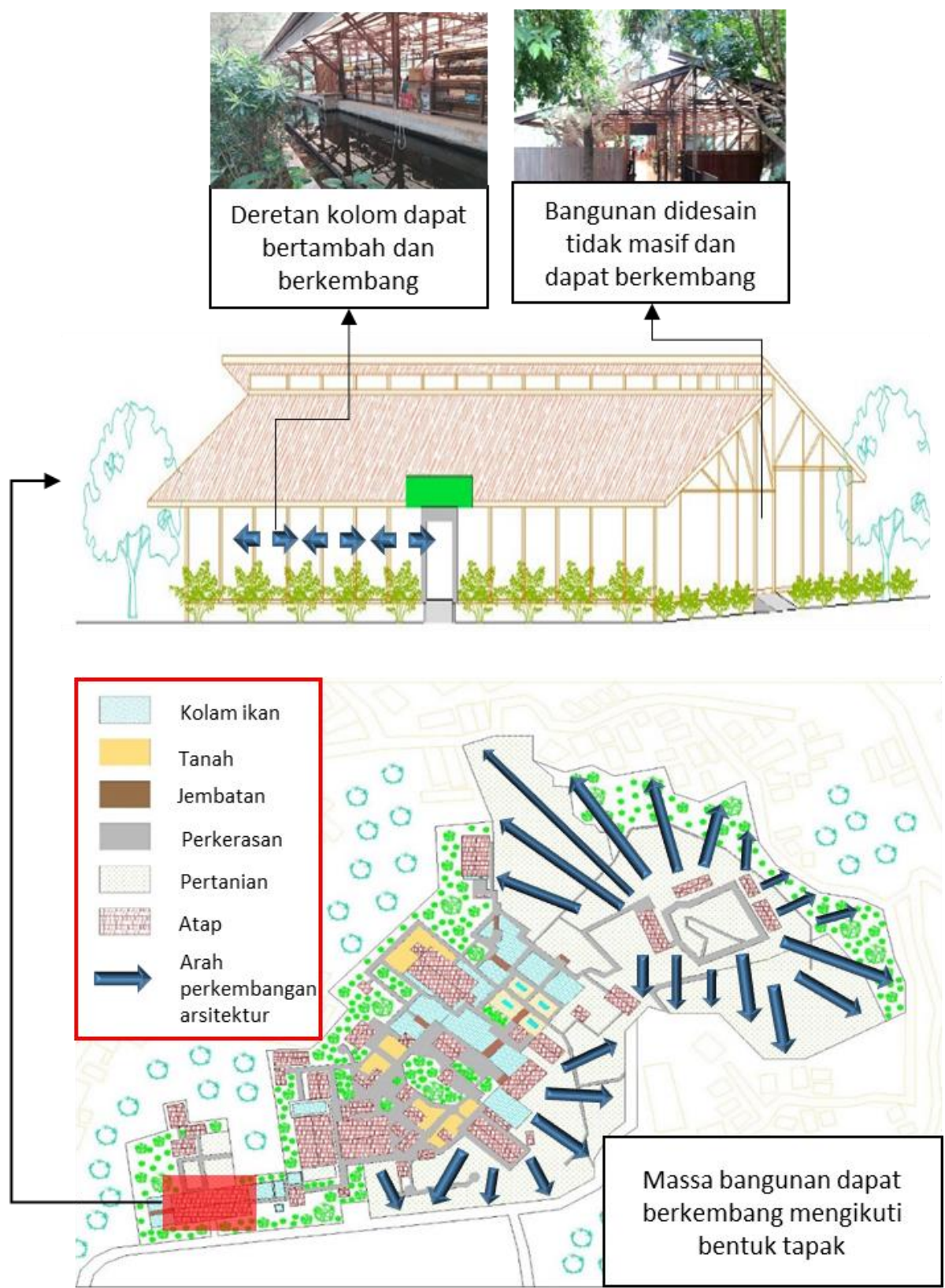

Gambar 3. Penerapan continuous present

mengikuti peprubahan zaman. Perkembangan desain tersebut dapat ke segala arah namun tetap mengikuti bentuk tapak yang ada. Selain itu, bangunan juga didesain tanpa dinding dan terbuka sehingga tidak masif. Desain bangunan yang tanpa dinding dan terbuka memungkinkan adanya perkembangan desain untuk merespon perubahan-perubahan yang terjadi disekitar seiring dengan perkembangan zaman (Lihat gambar 3). 


\section{Form follows flow}

Konsep form follows flow merupakan konsep yang diterapkan pada arsitektur dengan mengikuti aliran energi alam (Nagoy and Sela 2016). Form follows flow pada kawasan Kuntum Farmfield diterapkan dengan mendesain sisi terpanjang bangunan menghadap ke utara dan selatan yang menyesuaikan dengan arah lintasan matahari. Hal itu dilakukan untuk mengurangi panas matahari yang masuk ke dalam bangunan dengan menyesuaikan arah sinar matahari. Bangunan di kawasan ini juga didesain dengan menggunakan banyak bukaan untuk memungkinkan masuknya aliran udara. Bukaan-bukaan tersebut didesain berdasarkan aliran udara sebagai aliran energi yang banyak berhembus di kawasan ini. Selain itu, area belakang tapak juga didesain mengarah langsung ke arah pegunungan hijau yang indah. Pemandangan gunung yang indah merupakan sebuah energi yang dapat dimanfaatkan sebagai daya tarik dalam kawasan ini. Sehingga, kawasan Kuntum Farmfiled telah mengikuti dan mempertimbangkan aliran energi dalam merancang kawasan agrowisata modern (Lihat gambar 4).

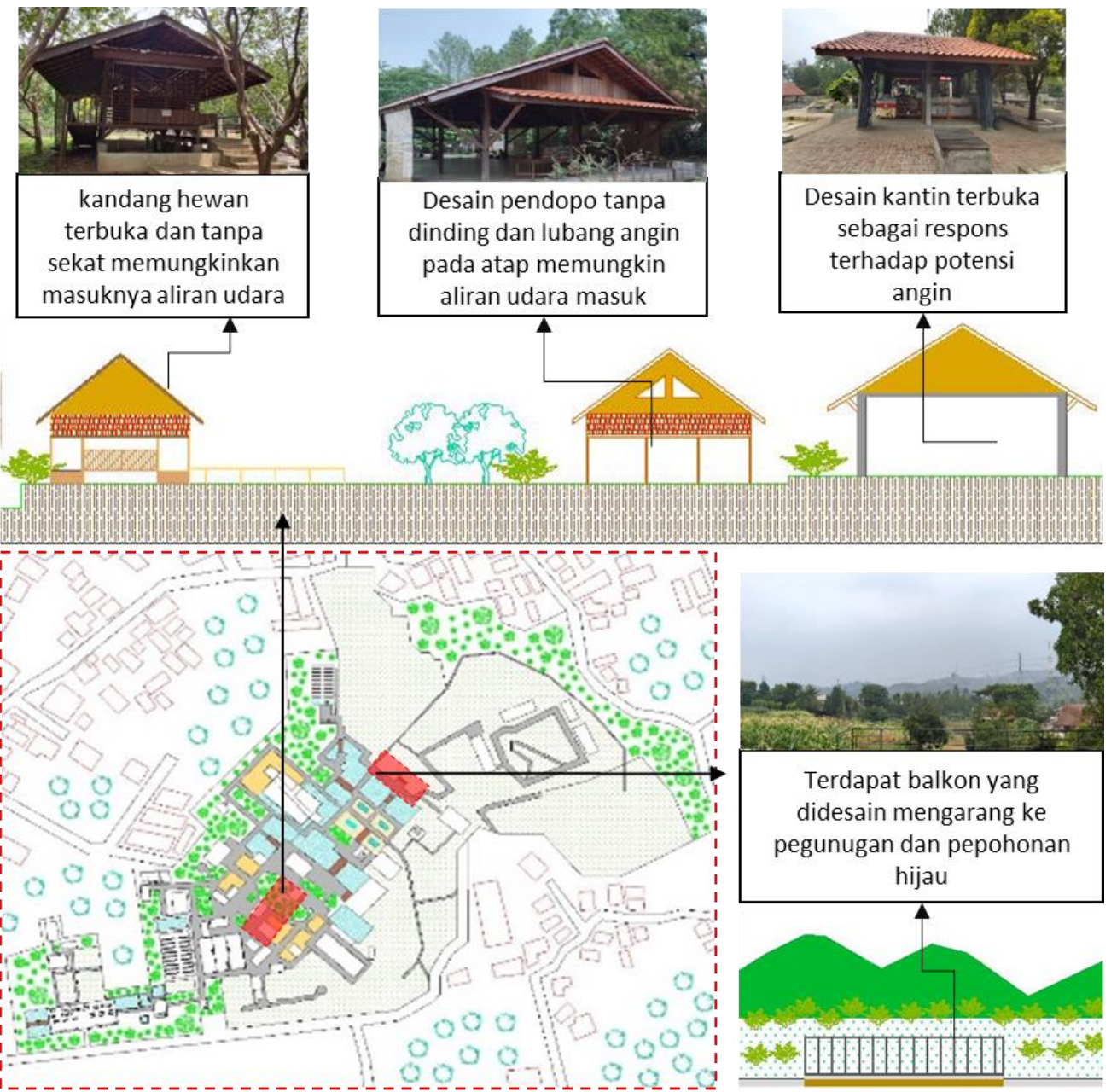

Gambar 4. Penerapan form follow flows

\section{Of the people}

Of the people merupakan konsep yang diterapkan pada arsitektur dengan penekanan khusus untuk memenuhi kebutuhan pemakai bangunan (Nagoy and Sela 2016). Of the people pada kawasan Kuntum Farmfield diterapkan dengan menyediakan ruang bagi pengunjung untuk berinteraksi dengan hewan yang letaknya berdekatan dengan kandang hewan. 
Keberadaan ruang yang dapat menampung orang banyak untuk berinteraksi dengan hewan ternak merupakan salah satu bentuk bawah kawasan ini telah memenuhi kebutuhan banyak pengunjung. Selain itu kawasan ini juga menyediakan pendopo yang dapat menampung banyak pengunjung untuk beristirahat setelah berkeliling kawasan. Pendopo-pendopo tersebut berada menyebar di seluruh tapak kawasan, sehingga mudah dijangkau oleh pengunjung. Sehingga, maka kawasan Kuntum Farmfield memperhatikan kebutuhan pengguna bangunan terutama pengunjung (Lihat gambar 5).

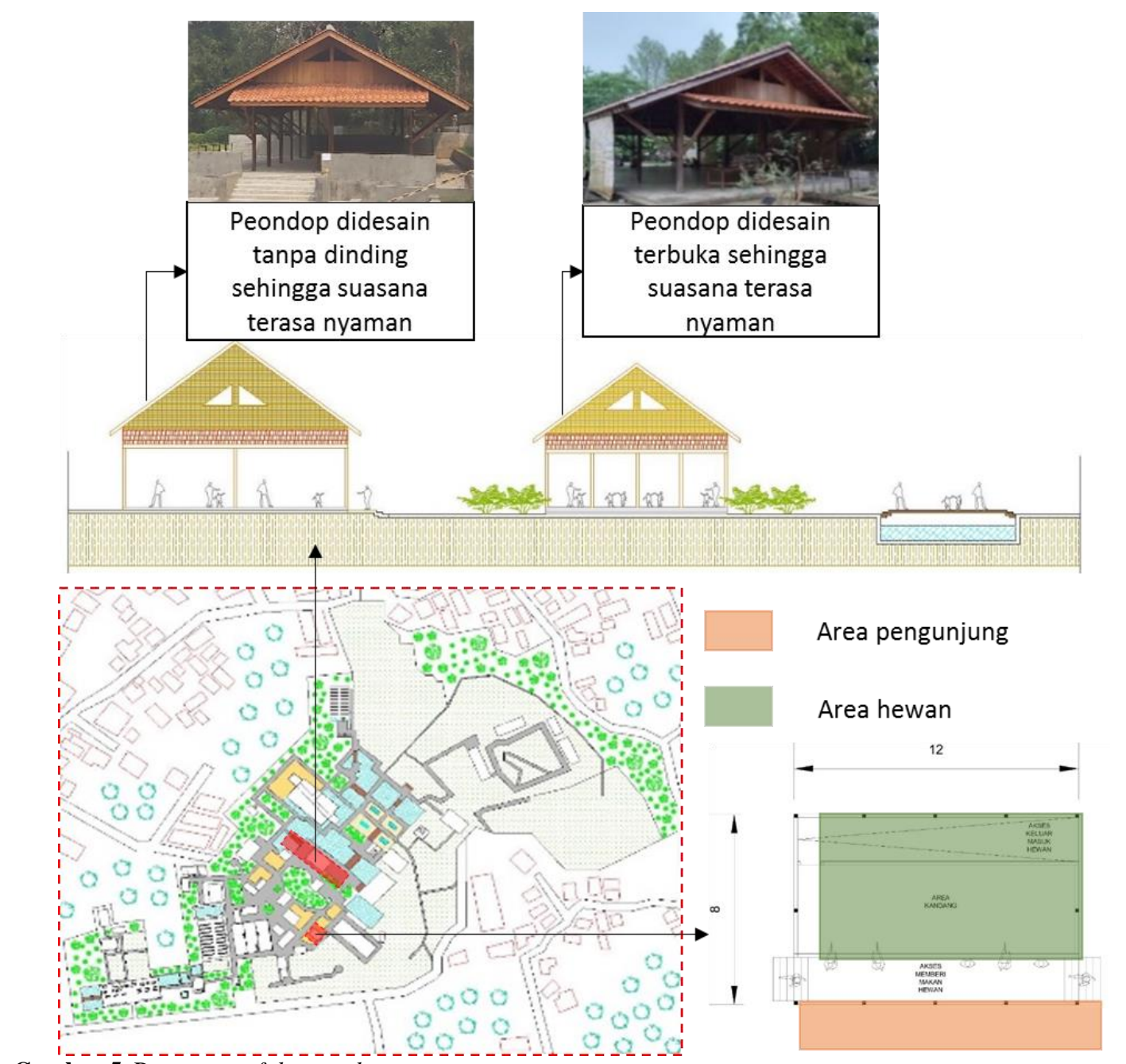

Gambar 5. Penerapan of the people

\section{Of the hill}

Of the hill merupakan konsep yang diterapkan pada arsitektur dengan meminimalisasi perataan kontur yang sudah ada pada tapak (Nagoy and Sela 2016). Of the hill pada kawasan Kuntum Farmfield diterapkan dengan meminimalisasi proses meratakan kontur yang dapat merusak ekosistem di dalam tanah. Hal tersebut dilakukan dengan menyesuaikan desain kawasan dengan kontur yang ada. Akibat adanya penyesuaian dengan kontur yang ada, tapak pada kawasan ini memiliki banyak kontur yang undak. Sehingga untuk memudahkan pengunjung dalam bersirkulasi pada tapak, tapak didesain dengan menghadiran banyak anak tangga maupun ramp. Dengan adanya kontur tersebut juga, kawasan menjadi terkesan unik karena terlihat seperti tumbuh dari kontur yang tidak beraturan. Sehingga, kawasan Kuntum Farmfield telah meminimalisasi perataan kontur pada tapak dengan tetap menghadirkan kontur pada tapak (Lihat gambar 6). 




Gambar 6. Penerapan of the hill

\section{Of the material}

Of the material merupakan konsep yang diterapkan pada arsitektur dengan menggunakan material-material bumi yang ramah lingkungan (Nagoy and Sela 2016). Of the material pada kawasan Kuntum Farmfield diaplikasikan dengan menggunakan material bumi pada struktur dan fasad bangunan. Struktur pada kawasan ini menggunakan kayu merbau yang ramah lingkungan. Kayu merbau merupakan material bumi dan ramah lingkungan karena memiliki massa termal yang rendah sehingga dapat menyesuaikan suhu ruang dengan iklim di kawasan Kuntum Farmfield. Dengan menggunakan material kayu merbau pada struktur bangunan yang terekspos, maka dapat memberikan efek yang teduh pada bangunan tersebut dan mengurangi energi untuk mendinginkan bangunan. Sedangkan, pada bagian fasad bangunan menggunakan material kayu kamper sebagai material arsitektural. Dengan demikian, maka kawasan Kuntum merupakan kawasan yang telah menggunakan material ramah lingkungan pada struktur dan fasad bangunan (Lihat gambar 7).

\section{Youthful and unexpected}

Youthful and unexpected merupakan konsep yang diterapkan pada arsitektur dengan menghadirkan aksen-aksen tidak terduga sehingga memberikan kesan yang menarik bagi pengunjung (Nagoy and Sela 2016). Youthful and unexpected pada kawasan Kuntum Farmfield diaplikasikan dengan menghadirkan jembatan kayu dengan material kayu merbau yang berada diatas kolam ikan pada tapak sehingga memberikan kesan menarik bagi pengunjung. Selain itu, bangunan pada kawasan ini didesain menggunakan struktur atap yang terbuka dan kolom-kolom kayu merbau yang terekspos, karena tidak menggunakan dinding pembatas. Dengan demikian, maka kawasan Kuntum Farmfield merupakan kawasan yang menarik bagi pengunjung, karena menghadirkan banyak aksen tidak terduga pada tapak kawasan (Lihat gambar 8). 


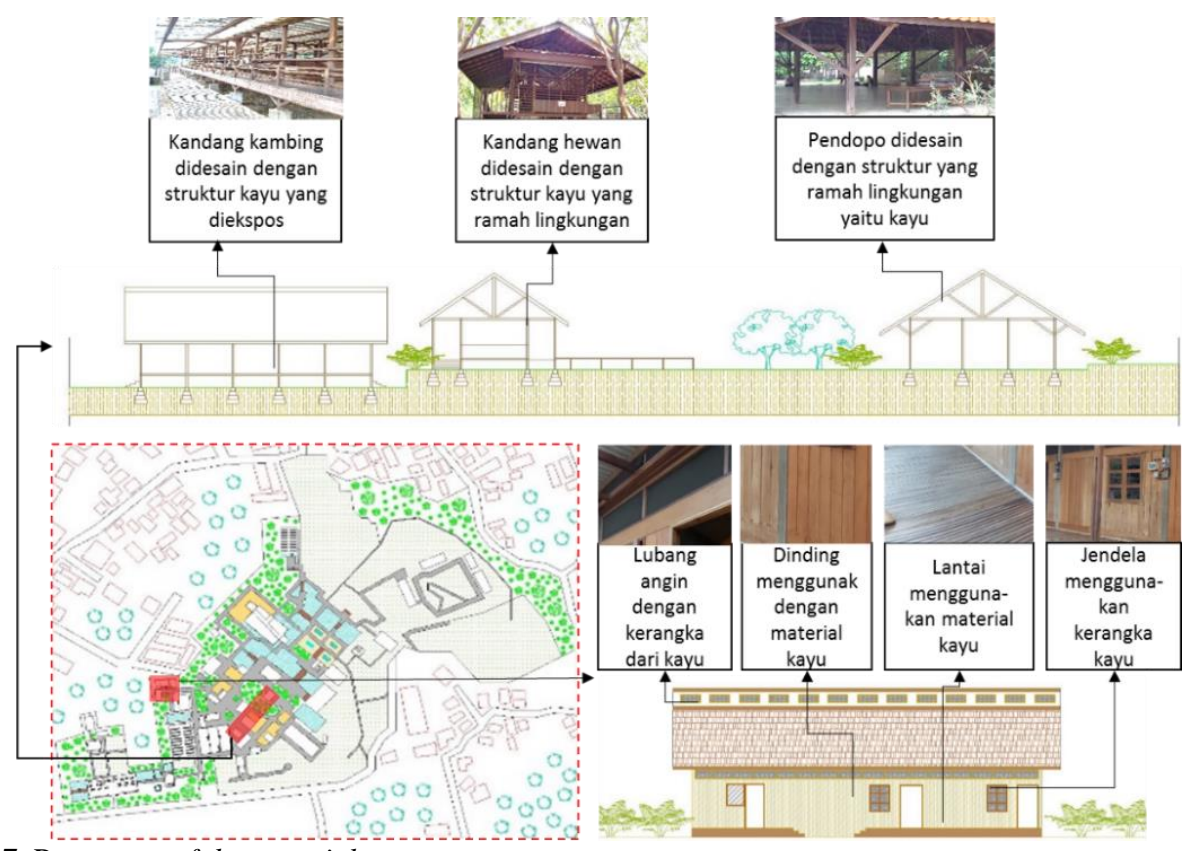

Gambar 7. Penerapan of the material

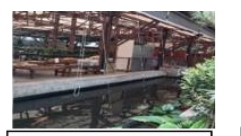

Meminimalisir penggunaan dinding
sehingga unsur alam sehingga unsur alam pada tapak dapat masuk ke dalam bangunan
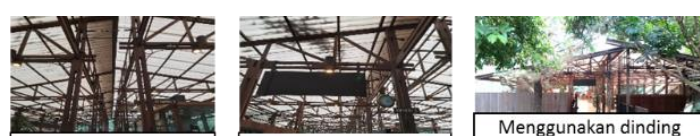

- the

Menggunakan

material atap yang transparan sehingga menjadikan ruangan

yang selalu terang

struktur kayu pada

Menggunakan dinding atap yang terekspos, sehingga memberikan kesan tersendiri bagi

seluruh bidang sehing

pengunjung dapat

menikmati lingkungan

sekitar dari dalam
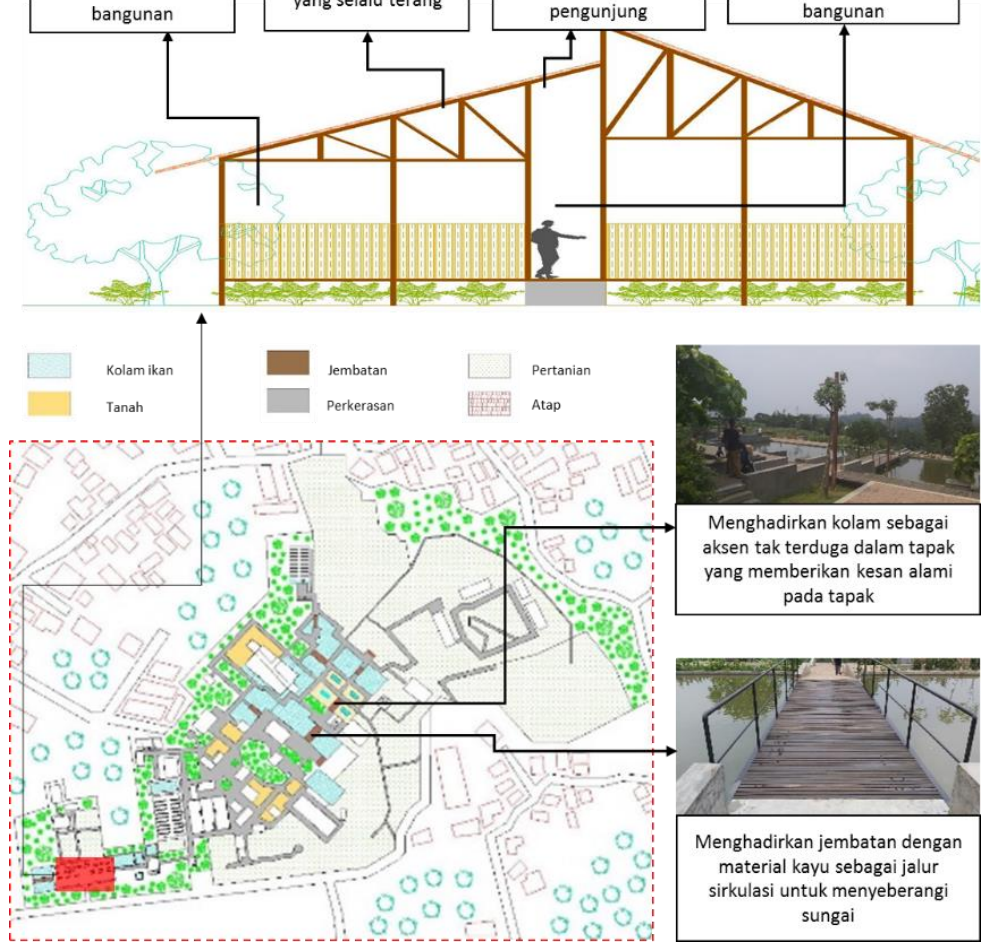

Gambar 8. Penerapan youthful and unexpected 


\section{Living music}

Living music merupakan konsep arsitektur yang diterapkan pada arsitektur dengan mendesain bangunan menggunakan pengulangan elemen-elemen yang dapat menimbulkan ritme bagi orang yang melihatnya (Nagoy and Sela 2016). Living music pada kawasan Kuntum Farmfield ditimbulkan akibat adanya deretan kolom kayu yang berulang pada bangunan di kawasan ini. Selain itu, pengulangan elemen- elemen pada kawasan ini juga dapat dilihat dari penggunaan jendela dan desain pintu pada bangunan. Jendela dengan ukuran dan jenis yang sama disusun berulang pada fasad bangunan. Desain pintu menggunakan deretan baja yang berukuran dan berjarak sama juga memberikan ritme bagi orang yang melihat. Dengan demikian, maka kawasan Kuntum Farmfield telah mengaplkasikan ritme pada desain bangunan pada kawasan (Lihat gambar 9).

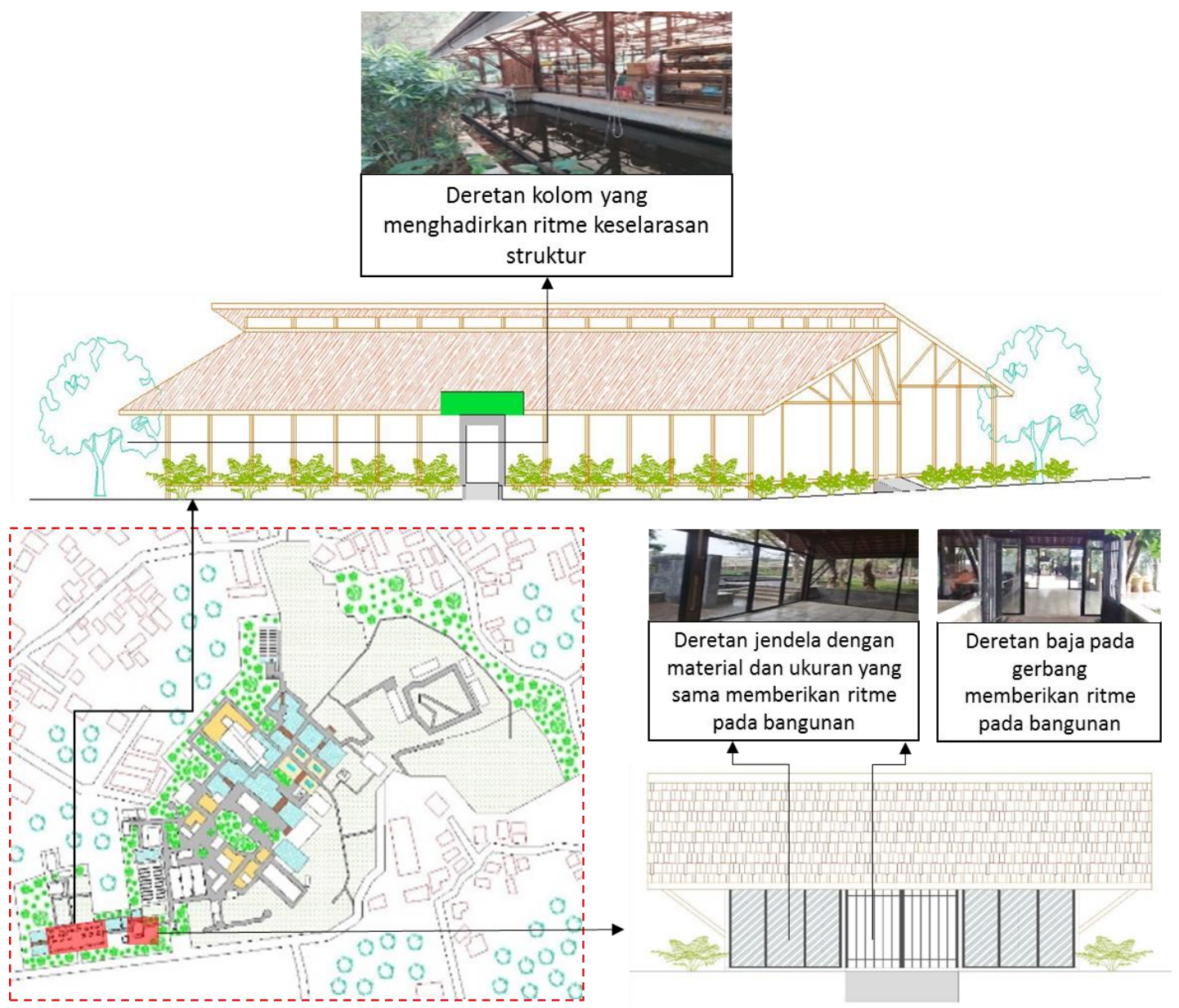

Gambar 9. Penerapan living musi

\section{Kesimpulan}

Penerapan arsitektur organik pada kawasan agrowisata modern dilakukan dengan menerapkan delapan konsep arsitektur organik. Delapan konsep arsitektur organik yaitu building is nature, continous present, form follows flow, of the people, of the hill, of the material, youthful and unexpected. Delapan konsep tersebut diterapkan pada bangunan dan tapak pada kawasan agrowisata modern.

Building is nature diterapkan pada kawasan agrowisata modern dengan mengaplikasikan gubahan massa yang terbuka, serta dengan menghadirkan unsur alam seperti air terjun, jembatan, sungai dan pepohonan pada tapak.

Continous present diterapkan pada kawasan agrowisata modern dengan mengaplikasikan 
sistem multi massa pada kawasan yang luas dan massa bangunan yang didesain tidak masif.

Form follows flow diterapkan pada kawasan agrowisata modern dengan mendesain sisi terpanjang bangunan mengarah ke Utara dan Selatan, mendesain bangunan dengan bukaan, dan mendesain area terbuka mengarah ke lingkungan alam yang indah.

Of the people diterapkan pada kawasan agrowisata modern dengan memberikan ruang yang cukup bagi pengunjung untuk berinteraksi dengan hewan dan mendesain bangunan dengan ruang terbuka yang dapat menampung orang banyak.

Of the hill pada kawasan agrowisata modern dapat diterapkan dengan menyesuaikan letak dan gubahan massa bangunan sesuai dengan kontur yang ada, mendesain area yang berkontur dengan air terjun dan bebatuan, dan menghidupkan area yang lebih tinggi dengan mendesain bangunan di atas kontur tersebut.

Of the material pada kawasan agrowisata modern dapat diterapkan dengan menggunakan material kayu dan batu alam yang ramah lingkungan pada eksterior dan interior bangunan.

Youthful and unexpected pada kawasan agrowisata modern dapat diterapkan dengan mendesain bangunan menggunakan struktur atap yang terbuka dan tidak menggunakan dinding masif sebagai penutup bangunan. Selain itu juga dengan mendesain tapak kawasan menggunakan unsur-unsur alam seperti, air terjun dengan bebatuan, kolam dan jembatan.

Living music pada kawasan agrowisata modern dapat diterapkan dengan mendesain bangunan dengan pengulangan material maupun elemen arsitektur pada eksterior dan interior bangunan.

\section{Referensi}

Basiya, R., and A. H. Rozak. 2012. 'Kualitas Dayatarik Wisata, Kepuasan Dan Niat Kunjungan Kembali Wisatawan Mancanegara Di Jawa Tengah'. Jurnal Ilmiah Dinamika Kepariwisataan 11 (2): 1-12.

Bawole, Paulus. 2020. 'Pengembangan Kampung Kota Sebagai Salah Satu Alternatif Tujuan Wisata Minat Khusus'. ARTEKS: Jurnal
Teknik Arsitektur 5 (1): 115-26. https://doi.org/10.30822/arteks.v5i1.362.

Dalawir, Alexander, Sonny Tilaar, and Hanny Poli. 2015. 'Sentral Industri Kain Koffo Di Manganitu (Arsitektur Organik)'. Jurnal Arsitektur DASENG 4 (1): 46-55. https://ejournal.unsrat.ac.id/index.php/daseng /article/view/6446/pdf.

Gunawan, I Made. 2016. 'Pengembangan Agrowisata Untuk Kemandirian Ekonomi Dan Pelestarian Budaya Di Desa Kerta, Payangan Gianyar'. JUMPA (Jurnal Master Pariwisata) 3 (1): 156-74. https://doi.org/10.24843/JUMPA.2016.v03.i0 1.p11.

Koy, Van Basten Maria Fernandes, and Olinda Rodrigues. 2019. 'Pengembangan Smart Environment Di Kampung Wisata Jetisharjo RW. 07, Yogyakarta'. ARTEKS: Jurnal Teknik Arsitektur 4 (1): 25-32. https://doi.org/10.30822/arteks.v4i1.75.

Masruroh, Fika, Lily Mauliani, and Anisa. 2015. 'Kajian Arsitektural Taman Yang Mengakomodasi Aksesibilitas Difabel Studi Kasus Taman Tribeca Central Park Mall, Taman Menteng Dan Taman Ayodia'. Nalars 14 (2): 145-67. https://doi.org/10.24853/nalars.14.2.\%25p.

Muzha, Vianda Kushardianti. 2013. 'Pengembangan Agrowisata Dengan Pendekatan Community Based Tourism (Studi Pada Dinas Pariwisata Kota Batu Dan Kusuma Agrowisata Batu)'. JAP (Jurnal Administrasi Publik) 1 (3): 135-41. http://administrasipublik.studentjournal.ub.ac .id/index.php/jap/article/view/81/75.

Nagoy, Windy, and Rieneka L. E. Sela. 2016. 'Optimalisasi Konsep Building as Nature Dari Pendekatan Arsitektur Organik Pada Kawasan Industri Peternakan Berkonsep Agrowisata'. Media Matrasain 13 (1): 56-67. https://ejournal.unsrat.ac.id/index.php/jmm/ar ticle/view/14522/14094.

Pamulardi, Bambang. 2006. 'Pengembangan Agrowisata Berwawasan Lingkungan (Studi Kasus Desa Wisata Tingkir, Salatiga)'. Diponegoro University. http://eprints.undip.ac.id/15372/1/Bambang_ Pamulardi.pdf.

Pudianti, Anna, and Vincentia Reni Vitasurya. 2019. 'Pendekatan Antropologi Sebagai Penyeimbang Model Perhitungan Jejak Ekologis Di Desa Wisata'. ARTEKS : Jurnal 
Teknik Arsitektur 4 (1): 33-44. https://doi.org/10.30822/arteks.v4i1.77.

Rahma, Femy Nadia, and Herniwati Retno Handayani. 2013. 'Pengaruh Jumlah Kunjungan Wisatawan, Jumlah Obyek Wisata Dan Pendapatan Perkapita Terhadap Penerimaan Sektor Pariwisata Di Kabupaten Kudus'. Diponegoro Journal of Economics 2 (2): $1-9$. https://ejournal3.undip.ac.id/index.php/jme/ar ticle/view/2919/2822.

Rasikha, Tezza Nur Ghina. 2009. 'Arsitektur Organik Kontemporer'. Universitas Indonesia.

http://www.beta.lecture.ub.ac.id/files/2014/0 6/MINGGU-14-ORGANIKKONTEMPOERER.pdf.

Rukayah, Siti. 2003. 'Penekanan Desain Arsitektur Organik Dan Green Architecture Pada Perancangan Pusat Rekreasi Dan Klub Pemancingan Di Rawapening, Kabupaten Semarang'. Modul 1 (1): 45-54. http://eprints.undip.ac.id/5935/1/45-tutut.pdf.

Setyoningrum, Ayu, and Anisa Anisa. 2019. 'Aplikasi Konsep Arsitektur Organik Pada Bangunan Pendidikan'. LANGKAU BETANG: JURNAL ARSITEKTUR 6 (1): 26. https://doi.org/10.26418/lantang.v6i1.32905.

Subroto, T. Yoyok Wahyu. 2019. 'Koeksistensi Alam Dan Budaya Dalam Arsitektur'.
ARTEKS : Jurnal Teknik Arsitektur 3 (2): vviii. https://doi.org/10.30822/artk.v3i2.244.

Suhato, Bambang. 2016. 'Strategi Pengembangan Wisata Agro Di Banyuwangi'. Jurnal Ilmiah Pariwisata $21 \quad$ (1): $1-15$. http://jurnalpariwisata.stptrisakti.ac.id/index. $\mathrm{php} / \mathrm{JIP} / \mathrm{article} / \mathrm{view} / 39$.

Sujanra, Song Prasetya, Ummul Mustaqimmah, and Agung Kumoro Wahyuwibowo. 2017. 'Penerapan Teori Arsitektur Oraganik Dalam Strategi Perancangan Pusat Pengembangan Industri Kreatif Di Bandung'. Arsitektura: Jurnal Ilmiah Arsitektur Dan Lingkungan Binaan 15 (2): 506-13. https://doi.org/10.20961/arst.v15i2.15316.

Susetyaningsih, Adi. 2013. 'Ekologi Industry Berbasis Daya Dukung Lingkungan Untuk Pengembangan Kawasan Wisata Agro Di Desa Barudua Kecamatan Malangbong Kabupaten Garut'. Jurnal Kalibrasi 11 (1). http://sttgarut.ac.id/jurnal/index.php/kalibrasi /article/view/108.

Widati, Titiani. 2015. 'Pendekatan Kontekstual Dalam Arsitektur Frank Lloyd Wright'. Jurnal Perspektif Arsitektur 10 (1): 38-44. https://ejournal.upr.ac.id/index.php/JTA/article/view/ $857 / 696$.

Widodo, Johannes. 2019. 'Human, Nature, And Architecture'. ARTEKS: Jurnal Teknik Arsitektur 3 (2): 145-48. https://doi.org/10.30822/arteks.v3i2.65. 
ARTEKS : Jurnal Teknik Arsitektur, Volume 5 Issue 2 August 2020

pISSN 2541-0598; eISSN 2541-1217 